\title{
Determination of Nitrogen Quantities in the Aminoacid Fertilizer with Kjeldahl Device
}

\author{
Elif Esra ALTUNER ${ }^{1}$, Yener TEKELi' ${ }^{2}$ \\ ${ }^{1}$ Department of Chemistry, Faculty of Science, Selçuk University, Konya-Turkey \\ ${ }^{2}$ Department of Pharmacy Technology, Faculty of Pharmacy, Adiyaman University, Adiyaman, Turkey \\ *Corresponding author's e-mail: ee_altuner@hotmail.com
}

\begin{abstract}
Nitrogen is the most important feed source for plants an essential element for plant growth and development (LiuCW et al.- 2014) because the cells are made of nitrogen. It is seen enhance in plant growth in the absence of nitrogen. Therefore, the most important nutrient source of the plant is nitrogen containing fertilizers. Fertilizers are divided into two main parts; organic fertilizers and chemical fertilizers. Organic fertilizers are healthier than chemical fertilizer because it does not conclude chemical substance. All cells are eminent from protein and many of amino acids carry out protein sequence. And amino acids has nitrogen (N) element In general, the nitrogen element is derived from amino acids in organic fertilizer sources from animal waste or vinasse. Nitrogen analysis is the most healthy method to determine with Kjeldahl instrument. The Kjeldahldevice is a nitrogen meter that determines the amount of nitrogen in the fertilizer. The nitrogen content of the Kjeldahlapparatus was determined by the amount of amino acids contained in the extract. Amino acids used as commercial fertilizers are amino acids used in the Lconformation in optical conditions, which are generally produced in laboratory conditions. Lysine is the main
\end{abstract} one.

Keywords- Aminoacid fertilizer, nitrogen, Kjeldahl device, Nitrogen meter.

\section{INTRODUCTION}

In order to obtain more and higher quality products and to improve the physical and chemical properties of the soil, fertilizer is called artificial organic fertilizer which contains plant nutrients.

With fertilization, the soil is enriched with plant nutrients. Water saving and ventilation is provided to the soil. The buffering properties and exchange capacity of the soil are regulated.

Both humans and animals need to increase the quality of agricultural materials.Fertilizers are divided into organic and chemical.

Organic fertilizers are divided into nitrogen fertilizers, phosphorus fertilizers, potassium fertilizers, trace element fertilizers, secondary element fertilizers and mixed fertilizers.

In this study, aminoacids fertilizer was studied as an artificial organic fertilizer.Due to the amino acid chains in its content, the amino acid fertilizer at hand contains three main nutrients, nitrogen, phosphorus and potassium. Since the amount of amino acid in the sample of this sample of lacquer is not known, this rich nitrogen analysis has been done.

Fertilizers are divided into organic and chemical fertilizers.

Chemical fertilizers are derived from urea, mono ammonium phosphate, di ammonium phosphate, nitric acid, potassium sulphate, potassium nitrate, boric acid, zinc sulphate hepta hydrate, manganese sulphate mono hydrate, iron sulphate hepta hydrate,copper sulphate hepta hydrate and many sources etc.

Organic fertilizers are made from animal and plant materials, including manure, worm castings, peat, seaweed, aminoacid and humic acid to name a few. Using organic fertilizers has been found to improve soil structure, microbial biomass and may lead to increased agriculture output (Sarker et al.- 2012) (Wiens JT-2107). In addition, some organic fertilizer have high nutritional elements that enhance plant growth and yields, while organic fertilizers may often be less expensive when compared to chemical fertilizers (Mantovi et al-2005). According to (Pascual et al-, 1997) and (Allenk et a.l1998), soil organic matter is an essential source of nutrients in order to maintain high microbial populations and activities in the soil. This in turn increases biomass for efficient basal respiration as well as improves total organic ratio in the soil. Animal manures, yard wastes, food wastes and compost are organic resources that are used to provide nutrients for plant growth and yield as well as maintain the fertility of the soil (Arancon et al.2005). Furthermore, residue and animal manure applications may lead to high crop production rates (Johnston et al-1995)

Organic fertilizers are divided into organic, unnatural organic and organic fertilizers, while chemical 
fertilizers are divided into nitrogen fertilizers, phosphorus fertilizers, potassium fertilizers, trace element fertilizers, secondary element fertilizers and mixed fertilizers. In this study, an amino acid fertilizer was studied as an artificial organic fertilizer. Due to the amino acid chains in its content, the aminoacid artificial fertilizer at hand contains three main nutrients, nitrogen, phosphorus and potassium. Since the amount of amino acid in the sample of this sample of lacquer is not known, this rich nitrogen analys is has been done.

The three main plant nutrients, N-P-K should contain high amounts of $\mathrm{Ca}, \mathrm{Mg}, \mathrm{S}$ and other micronutrient elements at the sametime.

It should be hard, round-grain (about $0.25 \mathrm{~cm}$ in diameter). It should not be affected by moisture as much as applied to the soil but it should be immediately soluble when applied to dry soils and should be fully usable for short season crops. Acidic soils should be given alkaline and alkaline soils should be given acidic fertilizers.

Once organic fertilizers are applied to soils and mineralization begins, inorganic nitrogen is released and absorbed by plants.(WiensJ.T-2107). However, the rate of mineralization is controlled by several factors, including agriculturalmanagement, microorganism, soil properties, temperature, and water content(Griffin TS-2008), (Dessureault-Rompré J.-2010),(Fan XH et a.l-2010) as well as the type of organic fertilizer (Lobell DB-2007). Many models have been developed to predict the release of nitrogen in applied organic fertilizers

Such standards, which matrix is commutable with patients' samples, compensate for the offset caused namely by lipids and bilirubin in most normal and partly in pathological patients sera and fertilizer samples (Vinlarkova B. et al.-2015).

\section{MATERİAL AND METHOD}

Nitrogen fertilizers are the most important fertilizer class. The most important nitrogen source is air. There is nitrogen in the air at $70 \%$.

But plants can not take nitrogen directly from air. For this reason, nitrogen is supplied to the plants through fertilizers. The most useful nitrogenous fertilizers are amino acid fertilizers. Through the use of amino acid fertilizer, both the protein requirement and the nitrogen requirement of the plant are ensured. (Vinklarkova $B$ et al.-2015)

There are 2 main classes of $\mathrm{N}$ fertilizers, solid and liquid.(Yoder N.-2014). Solid fertilizers are often incorporated into the soil before planting, liquid is generally applied post planting and is frequently applied season-long through irrigation. All of these organic materials are rich in slowreleasing organic $\mathrm{N}$ and the rate of mineralization make it difficult to predict when planning to meet crop uptake needs. In a 2006 study by Hartz and Johnstone, fish powder, blood meal and feather meal were all found to have very high levels of organic $\mathrm{N}$ (93\%-99\% of total $\mathrm{N}$ was in organic form). These fertilizer types and their application methods may provide $\mathrm{N}$ at different rates because they rely on soil microbes to convert organic $\mathrm{N}$ into inorganic $\mathrm{N}$ forms such as ammonium $(\mathrm{NH} 4+$ ) and nitrate $(\mathrm{NO} 3-)$ prior to plant uptake (Gaskell at al.- 2007) ( Yoder N.-2014).

In this study, the ratio of an amino acid containing gibbic nitrogen, which is present in the sample but whose nitrogen content is unknown, was analysed.

The Kjeldahldevice is assisted to determine the nitrogen content. (Vinlarkova B. et al.-2015).

The Kjedahl device we use is the Buchi Speed Digester $\mathrm{K}-436 / \mathrm{K}-439$. It is seen at fig 1 Kjeldahl device. (Operation manual SpeedDigester K-425 / K-436)

The Kjeldahl method was named after Johan Kjeldahl, who in 1883 developed the method for analysing nitrogen in organic substances. After historical improvement, nowadays Kjeldahl method can be divided into three main steps: digestion, distillation, titration. In the first step, sample is digested by sulphuric acid in the presence of catalyst to ammonia sulphate(LejskovaB.2016).

Organic $\mathrm{N}_{*}<\mathrm{H}_{2} \mathrm{SO}_{4}-\left(\mathrm{NH}_{4}\right)_{2} \mathrm{SO}_{4}+\mathrm{H}_{2} \mathrm{O}+\mathrm{CO}_{2}$ $+\mathrm{H}_{2} \mathrm{SO}_{4}+$ matrix by-products

All ammonia sulphate is converted in the distillation step into ammonia(LejskovaB.-2016):

$\left(\mathrm{NH}_{4}\right)_{2} \mathrm{SO}_{4}+<\mathrm{NaOH}-2 \mathrm{NH}_{3}+\mathrm{Na}_{2} \mathrm{SO}_{4}+2 \mathrm{H}_{2} \mathrm{O}+$ $\mathrm{NaOH}$

The liberated ammonia is distilled into a suitable receiving slution with boric acid, acidimetric indicator and water(LejskovaB.-2016):

$\mathrm{NH}_{3}+<\mathrm{H}_{3} \mathrm{BO}_{3} \quad \mathrm{NH}_{4} \mathrm{H}_{2} \mathrm{BO}_{3}+\mathrm{H}_{3} \mathrm{BO}_{3}$

The ammonium dihydrogen borate is titrated by sulphuric acid(LejskovaB.-2016):

$2 \mathrm{NH}_{4} \mathrm{H}_{2} \mathrm{BO}_{3}+\mathrm{H}_{2} \mathrm{SO}_{4}\left(\mathrm{NH}_{4}\right)_{2} \mathrm{SO}_{4}+2 \mathrm{H}_{3} \mathrm{BO}_{3}$

As boric acid captures ammonia gas, the colour of the indicator changes (LejskovaB.-2016).

Such a method is the determination of soil quality according ISO 11261:1995(ISO 11261:1995 soil Quaility-2016). This standard method was used to investigate the relationship between Kjeldahl nitrogen and organic carbon and to compare the methods for the determination of inorganic carbon by using dry combustion, loss on ignition and volumetric calcimeter in samples from river systems with low inorganic carbon content. Results from this article verified also proper function of apparatus(Regulation (EC) No 2003/2003). 


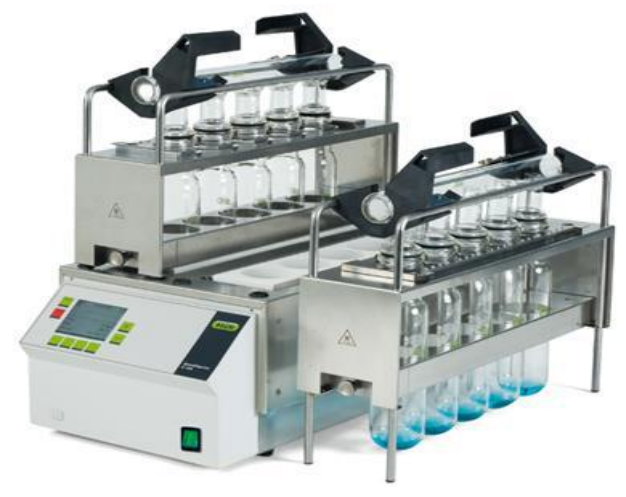

Fig.1: The Kjeldahl apparatus Buchi digester K 436/ K 439 , in which the nitrogen is determined by the amino acid stain (Operation manual SpeedDigester K-425 / K436)

Firsly, we wanted that porduce our fertilizer that content amino acid fertilizer. For this, all equipments of fertilizers were provided from İgsaş A.Ş-Turkey.

3 gram manganese sulphate mono hydrate were stirred in 54 grams distilled water until solving. Then, 12 grams iron sulphate hepta hydrate were added until solving. Then, 23 grams zinc sulphate hepta hydrate and 2 grams copper hepta hydrate were added with 0.60 gram sodium molybdate. Sodium molybdate were used for chelate. Finally, 4 grams amio acids (lysine) were added until solving.

We determinated nitrogen ratio of this fertilizer sample by Kjeldahl method.

\section{Determination of Nitrogen}

Nitrogen is found in many important substance as protein, fertilizer, explosives, drugs, pesticides and waters.

The most popular method for determining nitrogen is Kjeldahl method, devolop in 1883. It is based on the conversion of the bounded nitroge to ammonia $\left(\mathrm{NH}_{3}\right)$ which is then separated by distillation and determinated by titration.(Chromy V. et al-2017)

We carried out nitrogen determination analysis by Kjeldahl appratus (fig 1). And the needed chemicals were used that hydrogen chloride, sulphuric acid, sodium hidroxide ,kjeldahl tablets - each tablet 2grams - and the needed apparatus were used that weighing balance, kjeldahl appratus, volumetric flask, wask bottle, isomental, pipette, burette, pipette filler, magnetic stirrer, magnetic barr, beaker, funnel.

The hydrochloride acid, the sulphuric acide and the sodium hydroxide were used from sigma- aldrich.
The kjeldahl apparatus, Kjeldahl tablets , weighing balance, volumetric flask and the boric acid, were used from Anamed\& analytic group Ltd, Turkey.

The burette, pippette, burette stand, pipette filler, magnetic stirrer, magnetic barr, beaker, isomental and funnel were used from Labkon Ltd. Sti, Turkey.

For the $0.1 \mathrm{~N} \mathrm{HCl}$ Solution Preparation we took9,86 in a $100 \mathrm{ml}$ volumetric flask make up with distilled water(Chromy V. Et al-2015).

Forthe standardization of $\mathrm{HCl}$ titrate it against standardized $0,1 \mathrm{~N} \mathrm{NaOH}$ solution.

At the end pointcolourless of $\mathrm{NaOH}$ used $\mathrm{x}$ Normality $(0,1 \mathrm{~N}) /$ Volume of $\mathrm{HCl}(10 \mathrm{~mL})$

For $0.1 \mathrm{~N} \mathrm{NaOH}$ Solution we took $4 \mathrm{gm}$ of analtycal grade $\mathrm{NaOH}$ in $1 \mathrm{~L}$ vol. Flask make up with distilled water \&sonicate for 10 minutes.

For boric Acid $\%$ percentage Solution we took $20 \mathrm{mg}$ boric acid in a 1000 Volumetric Flask, add some distilled water and heat some time to dissolve the Boric Acid, make up with distilled water\&sonicate for 20 mins.

For the $32 \% \mathrm{NaOH}$ Solution we took $32 \mathrm{gm}$ $\mathrm{NaOH}$ in a 100 volumetric flask and add some distilled water to dissolve $\mathrm{NaOH}$, cool to room temperature\&make up with distilled water.To prevent to contamination by aerial ammonia, all reagents and solution were kept in tightly bottles and closed the Kjeldahl reaction immediately before use (Vinklarkova B. et al-2015).

\section{Analysis Method:}

For the sample digestion we took $0,7 \mathrm{~g}$ of sample in a Round Bottom Flask, then add $2 \mathrm{~g}$ of digestion Mixer in it, Rinse with water if necessary .

Add $15 \mathrm{~mL}$ of commercial $\mathrm{H}_{2} \mathrm{SO}_{4}$ in it and heat the sample for 1 hour 10 minutes at $100^{\circ} \mathrm{C}$, and then 45 minutes at 70-80 ${ }^{\circ} \mathrm{C}$ (Vinlarkova B. et al.-2015).

Cool digested sample to room temperature and add $70 \mathrm{~mL}$ distilled water in it (by adding water temp. Raised to $80^{\circ} \mathrm{C}$. Again cool sample to room temperature.) distilation:

Setting up KJELDAHL Apparatus for

Take $200 \mathrm{ml} 2 \%$ Boric Acid solution in the beaker and dip condenser in the beaker. Add $2 \mathrm{~g}$ devarda's Alloy in sample and then add $70 \mathrm{ml} 32 \% \mathrm{NaOH}$ solution drop by drop with dropping funnel after complete addition, swicth on Isomenta and start distillation. Distillate the sample for 1,5 hours at $100^{\circ} \mathrm{C}$.

And the titration was carried out. For this, titrate distillate with $0,1 \mathrm{~N}$ standardized $\mathrm{HCl}$. 

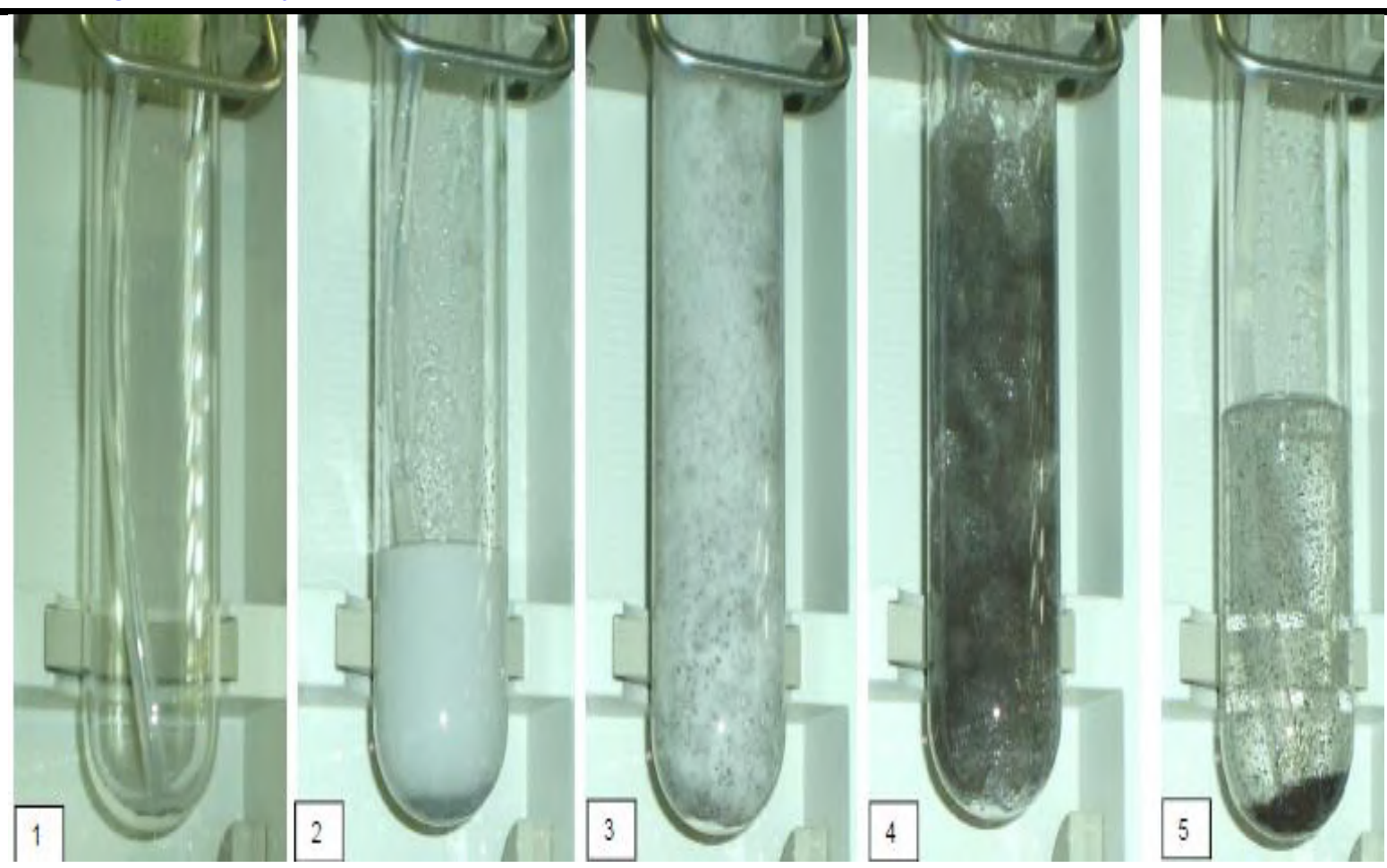

Fig.2: Devarda process at Kjeldahl device

III. RESULTS AND DISCUSSION

The digestion system was preheated at $420{ }^{\circ} \mathrm{C}$ and the samples were digested for 120 minutes at the temperature prior to distillation(Operation manual SpeedDigester $K-425$ / $K-436)$.

If the samples are not analysed on the same day, dilute them with $50 \mathrm{ml}$ of water in order to prevent crystallization. Otherwise, the reaction with the concentrated acid is violent and the sample may be lost. Gently swirl the tube to mix the digested sample with the water.

\section{Distillation and boric acid titration}

The Kjeldahl device unit was set according to the parameters list in the table 1

Table.1: The parameters of the used Kjeldahl apparatus

\begin{tabular}{|l|l|l|l|}
\hline \multicolumn{2}{|l|}{ Distillation } & \multicolumn{2}{l|}{ Titration } \\
\hline Water & $80 \mathrm{~mL}$ & Type & Boric acid \\
\hline $\mathrm{NaOH}$ & $90 \mathrm{~mL}$ & Titration solvent & $\mathrm{H}_{2} \mathrm{SO}_{4} .5 \mathrm{~N}$ \\
\hline Reaction time & $5 \mathrm{~s}$ & Volume receiving solvent & $60 \mathrm{~mL}$ \\
\hline Distillation time & $300 \mathrm{~s}$ & Min.titration time & $1 \mathrm{~s}$ \\
\hline Digested sample & + & Min.titration volume & $40 \mathrm{~mL}$ \\
\hline Reaction solution & + & Titration mode & standart \\
\hline Stirrer speed & 5 & Stirrer speed & 7 \\
\hline- & - & Titration $\mathrm{pH}$ measurement type & Endpoint \\
\hline- & - & Endpoint type & 4.65 \\
\hline
\end{tabular}

Firstly, we wanted before the determination of our nitrogen of fertilizer, we tried the Kjeldahl device for sodium nitrate (table 2)

Table.2: The results of the determination nitrogen content in sodium nitrate are presented

\begin{tabular}{|l|l|l|l|l|}
\hline Sample & m-sample(g) & V-sample (mL) & N & Recovery Rate \% \\
\hline Sample1 & 0.2571 & 6.321 & 16.646 & 101.5 \\
\hline Sample2 & 0.2505 & 6.039 & 16.296 & 99.36 \\
\hline Sample3 & 0.2515 & 6.074 & 16.328 & 99.56 \\
\hline Sample4 & 0.2512 & 6.067 & 16.328 & 99.27 \\
\hline
\end{tabular}




\begin{tabular}{|l|l|l|l|l|}
\hline Sample5 & 0.2575 & 6.196 & 16.28 & 99.55 \\
\hline Sample6 & 0.25 & 6.038 & 16.326 & 99.56 \\
\hline Sample7 & 0.2524 & 6.068 & 16.254 & 99.11 \\
\hline Sample8 & 0.2574 & 6.214 & 16.341 & 99.64 \\
\hline Sample9 & 0.2563 & 6.214 & 16.373 & 99.65 \\
\hline Sample10 & 0.2568 & 6.107 & 16.342 & 99.78 \\
\hline Sample11 & 0.2527 & 6.143 & 16.364 & 99.82 \\
\hline Sample12 & 0.2539 & 6.253 & 16.271 & 99.64 \\
\hline Sample13 & 0.2585 & 6.237 & 16.341 & 99.78 \\
\hline Sample14 & 0.2583 & 6.201 & 16.363 & 99.82 \\
\hline Sample15 & 0.2564 & 6.117 & 16.36 & 99.8 \\
\hline Sample16 & 0.2527 & 6.110 & 16.363 & 99.65 \\
\hline Average $(\%)$ & - & - & 16.35 & 99.7 \\
\hline SD & - & - & 0.5 & 0.5 \\
\hline Rsd $(\%)$ & - & - & 0.3 & 0.3 \\
\hline
\end{tabular}

Finding conlusions were presented table 3 . We found the the nitrogen ratio of amino acid $3.13 \%$ ( $3 \%$ ).

Table.3: The conclusion as to parameters of the sample

\begin{tabular}{|l|l|l|l|l|l|}
\hline & Weight (g) & Weight (g) & Weight (g) & & \\
\hline Weight & 0.8510 & 0.7580 & 0.8967 & & \\
\hline Blind(mL) & 0.2 & 0.2 & 0.2 & Average & \\
\hline $\mathrm{VH}_{2} \mathrm{SO}_{4} \cdot \mathrm{N} 0,5$ & 3.1 & 3 & 3.3 & 3.13 & \\
\hline
\end{tabular}

The amino acid content of unknown nitrogen fertilizer content was determined as $3 \%$ in the Kjeldahl instrument again. We repeated same analysis again by Kjeldahl device.

We used the volume of sample titrant $(\mathrm{HCl}) 50 \mathrm{ml}$, volume of sample blank $49,7 \mathrm{ml}$ and normality $0,5 \mathrm{~N}$ for the 0.7 g amino acid sample.

We calculated the conclusion following this equality:

Nitrogen $\%=$ (Volume of sample titrant-Volume of titrant blank) x Normality x1,401 /Weight of Sample

Nitrogen $\%=(50 \mathrm{~mL}-49,7 \mathrm{~mL}) \mathrm{x} \quad 1,401 \mathrm{x} \quad 0,5 \mathrm{~N} / 0,7 \mathrm{~g}$ $=3$

Nitrogen $\%=3$.

According to these two-repeated samples our amino acid ratio fertilizer is $3 \%$.

\section{CONCLUSION}

We can say all nitrogen analysis of fertilizers and food can analysis with Kjeldahl device apparatus. Kjeldahl apparatus give us the ratio of nitrogen true. Also, the new methods of this apparatus can improve for different fields.

The Kjeldahl method for determination is referred in all standard textbooks of clinical chemistry as a clasical method generally accepted as reference method on which other methods are based (Chromy V. et al.2015) (Vinklorkova B. et al.- 2015)

\section{Data Availability}

The data used to support the findings of this study are available from corresponding upon request.

\section{Conflicts of Interest}

The authors declare that there are no conflicts of interest regarding the publication of this paper.

\section{Disclosure}

The research did not receive specific funding, but was performed as part of employment of the company Sector Agriculture A.Ş, Konya, Turkey..

\section{REFERENCES}

[1] Allen, Michael F, \& Zink, Thomas A., The effects of organic amendments on the restoration of a disturbed coastal sage scrub habitat. Restoration Ecology, 6(1), 52-58-1998

[2] Arancon, Norman Q, \& Edwards, Clive A. ,Effects of vermicomposts on plant growth. Soil Ecology Laboratory, The Ohio State University, Columbus, $\mathrm{OH}, 43210-2005$

[3] Cheng-Wei L., Yu S., Bo-Ching C., Hund-Yu LaEffects of Nitrogen Fertilizers on the Growth and Nitrate Content of Lettuce (Lactuca sativa L.) China-2014

[4] Chromy V., Vinklarkova B., Sprongl L., Bittova M., Zaludova L., Changes in Proteins Noticed in 
Reconstituted Freeze-Dried Reference Materials Used in Clinical Chemistry as Calibrators and/or Controls, Klin. Biochem. Metab, Checzh Republic2016

[5] Chromy V., Vinklarkova B., Šprong1 L., Bittova M.: The Kjeldahl method as a primary reference procedurefor the determination of total protein in certified reference materials used in clinical chemistry. I. A Review of Kjeldahl Methods Adopted by Laboratory Medicine. Crit Rev Anal Chem, 45: p. 106-111. , Checzh Republic ,-2015

[6] Dessureault-Rompré J., Zebarth B.J., Burton D.L., Sharifi M., Cooper J., Grant C.A., Drury C.F. Relationships among mineralizable soil nitrogen, soil properties, and climatic indices. Soil Sci. Soc. Amer. J. ;74:1218-1227.-2010

[7] Fan X.H., Li Y.C. Nitrogen release from slowrelease fertilizers as affected by soil type and temperature. Soil Sci. Soc. Amer. J.; 74:1635-1641 $-2010$

[8] Gaskell, M. and R. Smith., Nitrogen sources for organic vegetable production. HortTechnology 17:431-441.- 2007

[9] Griffin T.S. Nitrogen Availability. In: Schepers J., Raun W.R., editors. Nitrogen in Agricultural Systems.SSSA Inc. and ASA Inc.; Madison, WI, USA. pp. 613-646-2008.

[10] ISO 11261:1995: Soil quality - Determination of total nitrogen - Modified Kjeldahl method, [online]. [cit 10. 7. 2016]

[11] Johnston, AM, Janzen, HH, \& Smith, EG.,Longterm spring wheat response to summerfallow frequency and organic amendment in southern Alberta. Canadian Journal of Plant Science, 75(2), 347-354-1995

[12] Lejskova B., Optimization of the determination of total protein in biological samples and reference materials used in clinical chemistry, Phd Thesis, MAsaryk University,Departmenf of Chemistry , Czech Republic-2016

[13] Mantovi, Paolo, Baldoni, Guido, \& Toderi, Giovanni. Reuse of liquid, dewatered, and composted sewage sludge on agricultural land: effects of long-term- application on soil and crop. Water research, 39(2), 289-296. -2005

[14] Regulation (EC) No 2003/2003 of the European Parliament and of the Council of 13 October 2003 relating to fertilisers (Text with EEA relevance), [online]. [cit 10. 7. 2016] http://eurlex.europa.eu/homepage.htm

[15] Operation manual SpeedDigester K-425 / K-436
[16] Lobell D.B. The cost of uncertainty for nitrogen fertilizer management: A sensitivity analysis. Field Crop. Res. 2007;100:210-217 -2007

[17] Pascual, JA, Garcia, C, Hernandez, T, \& Ayuso, M.,. Changes in the microbial activity of an arid soil amended with urban organic wastes. Biology and Fertility of soils, 24(4), 429- 434. -1997

[18] Sarker, Ashoka, Kashem, Md Abul, \& Osman, Khan Towhid. Comparative Effect of City Finished Compost and NPK Fertilizer on Growth and Availability of Phosphorus to Radish (Raphanus sativus L.). Open Journal of Soil Science, 2(02), 146.-2012

[19] Wiens J.T , Agronomic and Enviromental Effects of Phosphorus Fertilizer Application Methods, Msc Thesis, University of Saskatchewan, Saskatoon2017

[20] Vinklarkova B., Chromy V., Sprongl L., Bittova M., rikanova M., rikanova M., Ohnutkova I., Zaludova L., The Kjeldahl Method as a Primary Reference Procedure for Total Protein in Certified Reference Materials Used in Clinical Chemistry. II. Selection of Direct Kjeldahl Analysis and Its Preliminary Performance Parameters. Critical Reviews in Analytical Chemistry, Checzh Republic - 2015

[21] Vinklarkova B., Chromy V., Bittova M., Sprong1 L., Zaludova L., Simplified direct Kjeldahl method suitable as a primary reference procedure for the determination of total protein in reference materials used in clinical chemistry, Klin. Biochem. Metab., Checzh Republic -2015

[22] YoderN., Organic Fertilizer Comparison on Kale (Brassica spp. ) Varietal Growth and Nutrient Content, Msc Thesis, Department of Horticulture, Colorodo-2014 